\title{
Antimicrobial Resistance: The Key to Integrative Medicine in Primary Care?
}

\author{
Esther van der Werf \\ University of Bristol, Bristol Medical School, Population health Sciences, Bristol, United Kingdom
}

Submission: November 14, 2017; Published: May 04, 2018

*Corresponding author: Esther van der Werf, Canynge Hall, 39 Whatley Road, Bristol, BS8 2PS, Email: Esther.vanderwerf@bristol.ac.uk

\section{Primary Care and Antimicrobial Resistance (AMR)}

In the United Kingdom nearly eighty percent of antibiotics are prescribed in primary care, making it one of the most important contributors to the development of antimicrobial resistance (AMR) [1]. Reducing the use of antibiotics in primary care and controlling the development of AMR are pressing national and international priorities.

\section{Respiratory Tract Infection (RTI)}

General practice consultation rates in England and Wales show that a quarter of the population will visit their GP because of a respiratory tract infection (RTI) each year [2]. The diagnosis and management of RTIs varies considerably between clinicians, GP practices and countries, suggesting clinical uncertainty regarding optimum treatment. Recommended management for most patients with RTI involves self-care and treatment of symptoms [3]. Nevertheless antibiotics are commonly prescribed for RTIs in adults and children in primary care, and are the reason for $60 \%$ of all antibiotic prescribing in general practice in the UK [4]. Previous studies show that antibiotics have small or negligible symptomatic benefits for patients with acute otitis media (AOM), pharyngitis, bronchitis, laryngitis and common cold, and that widespread use of antibiotics for infections, including the common cold, sore throats, and the flu is prevalent in paediatric practice [5-8].

\section{Urinary Tract Infection (UTI)}

Urinary tract infections (UTIs) are the most common confirmed bacterial infection managed in primary care, with about half of all women experiencing one of more UTI in their life time [9]. Between $20 \%$ and $30 \%$ of women will experience a recurrence, and around $25 \%$ will develop ongoing recurrent episodes, with implications for individual well-being and healthcare costs [10]. Most women with UTIs are currently treated with antibiotics, making it one of the most important contributors to the development of AMR in primary care (with longer duration, multiple courses associated with higher AMR rates $[11,12]$. Finally, antibiotic use has short and long term effects, including side effects (e.g. diarrhoea, candidiasis) and microbiome disruption (which may take as long as 4-years to return to pre-treatment levels) [13].
Role of Complementary and Alternative Medicine (CAM)

CAM might be able to contribute to a reduction in antibiotic use. On the one hand, CAM therapies, which are proven effective and safe, could be used to strengthen the self-healing capacities of the organism (preventive and curative health promotion). Here CAM is an alternative for antibiotics but is not directly based on the antimicrobial properties of the product itself. On the other hand, several CAM products may act as a nonantibiotic treatment strategy (fighting disease strategies) to control infectious diseases based on their own (bactericide or bacteriostatic) antimicrobial properties.

\section{CAM, Antimicrobial Stewardship and Antimicrobial} Resistance

The increase of antibiotic resistance worldwide, rising numbers of deaths and costs associated with this, and the fact that hardly any new antimicrobial drugs have been developed during the last decade have increased interest in Integrative Medicine (IM) therapeutic interventions, if proven safe and effective. However, worldwide research in IM/CAM is seriously hampered by a lack of research infrastructure and funding, lack of appropriate research models and strategies, and the scepticism of the conventional scientific community.

Now, it is time to bridge the academic knowledge of IM/CAMand conventional experts for the integration of possible CAM contributions into conventional medicine, especially in primary care, with the ultimate goal to reduce inappropriate antibiotic consumption (antimicrobial stewardship) and AMR.

\section{Conflict of Interest}

None

\section{References}

1. Public Health England. English surveillance programme for antimicrobial utilisation and resistance (ESPAUR).

2. Ashworth M, Charlton J, Ballard K, Latinovic R, Gulliford M, et al. (2005) Variations in antibiotic prescribing and consultation rates for acute respiratory infection in UK practices $1995-2000$. Br J Gen Pract 55: 603-608. 
3. Stanton N, Francis NA, Butler CC (2010) Reducing uncertainty in managing respiratory tract infections in primary care. Br J Gen Pract 60(581): 466-475.

4. Gulliford MC, Dregan A, Moore MV, Ashworth M, Staa TV, et al. (2014) Continued high rates of antibiotic prescribing to adults with respiratory tract infection: survey of 568 UK general practices. BMJ Open 4(10): $\mathrm{e} 006245$.

5. Kenealy T, Arroll B (2013) Antibiotics for the common cold and acute purulent rhinitis Cochrane Cochrane Database Syst Rev, doi: 10.1002/14651858.CD000247.pub3.

6. Smith SM, Fahey T, Smucny J, Becker LA (2014) Antibiotics for acute bronchitis. Cochrane Database Syst Rev, doi: 10.1002/14651858. CD000245.pub3.

7. Spinks A, Glasziou PP, Del Mar CB (2013) Antibiotics for sore throat. Cochrane Database Syst Rev, doi: 10.1002/14651858.CD000023.pub4.

8. Venekamp RP, Sanders SL, Glasziou PP, Del Mar CB, Rovers MM, et al. (2013) Antibiotics for acute otitis media in children. Cochrane Database Syst Rev, doi: 10.1002/14651858.CD000219.pub3.

This work is licensed under Creative

Commons Attribution 4.0 License

DOI: 10.19080/JCMAH.2018.06.555681
9. Foxman B (2003) Epidemiology of urinary tract infections: incidence, morbidity, and economic costs. Dis Mon 49(2): 53-70

10. Flower A, Wang LQ, Lewith G, Liu JP, Li Q (2015) Chinese herbal medicine for treating recurrent urinary tract infections in women Cochrane Database Syst Rev, doi: 10.1002/14651858.CD010446.pub2.

11. Bryce A, Hay AD, Lane IF, Thornton HV, Wootton M, et al. (2016) Global prevalence of antibiotic resistance in paediatric urinary tract infections caused by Escherichia coli and association with routine use of antibiotics in primary care: systematic review and meta-analysis. BMJ, doi: 10.1136/bmj.i939.

12. Costelloe C, Metcalfe C, Lovering A, Mant D, Hay AD, et al. (2010) Effect of antibiotic prescribing in primary care on antimicrobial resistance in individual patients: systematic review and meta-analysis. BMJ, doi: 10.1136/Bmj.C2096.

13. Jakobsson HE, Jernberg C, Andersson AF, Sjölund-Karlsson M, Jansson JK, et al. (2010) Short-term antibiotic treatment has differing longterm impacts on the human throat and gut microbiome. PloS one 5(3): e9836.

\section{Your next submission with Juniper Publishers} will reach you the below assets

- Quality Editorial service

- Swift Peer Review

- Reprints availability

- E-prints Service

- Manuscript Podcast for convenient understanding

- Global attainment for your research

- Manuscript accessibility in different formats

( Pdf, E-pub, Full Text, Audio)

- Unceasing customer service

Track the below URL for one-step submission https://juniperpublishers.com/online-submission.php 